\title{
Copyright, Exhaustion, and the Role of Libraries in the Ecosystem of Knowledge
}

\author{
ARIEL KATZ*
}

CONTENTS

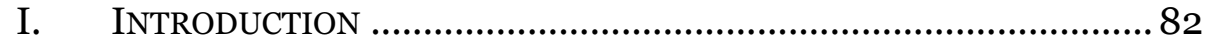

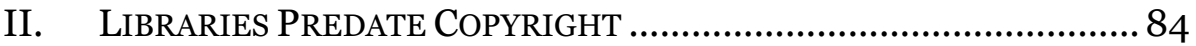

III. The PlaUsibILITY OF DigITAL EXHAUSTION ................................ 88

A. Kirtsaeng v. John Wiley \& Sons: Life Beyond s 109(a) .........88

B. Exhaustion Beyond Distribution .......................................... 92

IV. THE LIMITS OF PRIVATE REORDERING ............................................ 95

A. Exhaustion: Limits on Contract and License Override ........ 95

B. Towards a Digital Restraint of Trade Doctrine.................... 99

V. Digital EXHAUSTION AND THE CASE OF LIBRARIES .................... 103

A. Why Do Libraries Even Exist?............................................ 103

B. Libraries Mitigate a Web of Market Failures ..................... 104

C. Technology Contingent, Endemic, and Strategic Impediments to Access...........................................................105

1. Technology Contingent Impediments .............................. 106

2. Endemic Impediments.......................................................107

3. Strategic Impediments ..................................................... 109

D. Price Discrimination and Impediments Thereto..................110

E. Alternatives to Direct Price Discrimination ........................ 115

F. Indirect Price Discrimination: Bundling, Sharing, and Libraries .............................................................................. 117

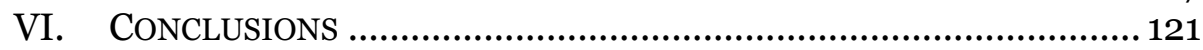

* Ariel Katz is an Associate Professor, Innovation Chair-Electronic Commerce, Faculty of Law, University of Toronto. Many thanks to Guy Rub, Margot Kaminski, Peter Shane, Matthew Marinett, Pietro Cimino, and the participants of the I/S Symposium on The Future of Libraries in the Digital Age for their helpful comments and suggestions. 


\section{INTRODUCTION}

American book and journal publishers sold 2.7 billion units in 2014, generating $\$ 27.98$ billion in net revenue. ${ }^{1}$ Meanwhile, libraries in the United States circulate almost twice that amount, engaging in over 4.42 billion circulation transactions a year, ${ }^{2}$ most of which are for free. Presumably, most of the works that libraries circulate are under copyright, and the Copyright Act grants to the owner of the copyright the exclusive right "to distribute copies or phono records of the copyrighted work to the public by . . . lending." 3 Nevertheless, libraries continue to circulate such a vast number of works, without seeking permission from the owners of the copyright or paying any royalties, because the first-sale doctrine, now codified in section 109(a), allows them to do that. Moreover, libraries benefit from the first-sale doctrine not only when they circulate materials, but also when they acquire them. The first-sale doctrine makes it easier for libraries to build their collections because those who sell them lawfully made copies do not need to obtain the copyright owners' permission to do so. Thus, distributors and resellers of in-print books or out-of-print books, and owners of new books or used ones, can all sell, give, or lend them to libraries without worrying about copyright law. 4 This ecosystem, where market-based remunerated transactions constitute only a subset of a much larger number of non-market and nonremunerated transactions, has existed for generations-probably ever since publishers published books and libraries circulated them-and publishers have been doing just fine.

But this ecosystem is currently under pressure. Rumor has it that the first-sale doctrine is dying. ${ }^{5}$ According to the rumor, the first-sale

\footnotetext{
${ }^{1}$ Marisa Bluestone, U.S. Publishing Industry's Annual Survey Reveals \$28 Billion in Revenue in 2014, ASs'N OF AM. PUBLISHERs, http://publishers.org/news/us-publishingindustry\%E2\%80\%99s-annual-survey-reveals-28-billion-revenue-2014 [https://perma.cc/526T-8PA8].

2 Brief for Am. Lib. Ass'n et al. as Amici Curiae Supporting Petitioner at 3, Kirtsaeng v. John Wiley \& Sons, Inc., 133 S. Ct. 1351 (2013) (No. 11-697).

317 U.S.C. § 106(3) (1976).

4 See Kirtsaeng v. John Wiley \& Sons, Inc., 133 S. Ct. 1351, 1366 (2013).

5 The analysis and critique of the "death prognosis" is based on Ariel Katz, Digital Exhaustion: North American Observations, in RESEARCH HANDBOOK ON ELECTRONIC COMMERCE LAW 137 (John A. Rothchild ed., 2016).
} 
doctrine, forged in the era of the physical copy and limited to the distribution of physical copies, will lose its prominence in the brave new digital world, where works in digital formats are no longer distributed and enjoyed as particular identifiable objects. ${ }^{6}$ The firstsale doctrine may not disappear altogether, but history may relegate it to the geriatric departments of culture and knowledge, together with yellowing used books, dusty records, and crumbling films.

This "death prognosis" further relies on the proliferation of contractual and licensing conditions that purport to prohibit one buyer from transferring what she purchased to another, even if such a transfer were otherwise technically possible and legally permissible. ${ }^{7}$ If those restrictive conditions are enforceable (and many assume they usually are), then the first-sale doctrine may be legally alive, but practically dead.

If the death prognosis is accurate, it implies a rather dim future for libraries-at least as we know them. Libraries may not disappear altogether, but will slowly function less as libraries and more as archives. Or perhaps some of their functions will be taken over by commercial enterprises (imagine iTunes, Spotify, or Netflix for books or journal articles), or might require separate licensing arrangements. For this shift to happen, two propositions must be true. First, as a legal matter, it must either be the case that the that the first-sale doctrine applies only to physical copies and not to digital copies, or that the doctrine does apply to digital copies, but contractual and licensing limitations on the doctrine are unquestionably enforceable. Second, if commercial enterprises were to replace libraries, then, as an economic matter, business models that perform the functions that libraries currently perform must be viable.

In this paper, I challenge both of these propositions. First, as a legal matter, the rumor of the doctrine's demise, while taken for granted by many commentators, is far from being a foregone conclusion. Notwithstanding views to the contrary, the Copyright Act does not preclude courts from applying the principle of exhaustion to the transfer of digital files. Likewise, the general enforceability of contractual and licensing limitations on the doctrine should not be taken for granted. Second, as an economic matter, many of libraries'

\footnotetext{
${ }^{6}$ Aaron Perzanowski \& Jason Schultz, Legislating Digital Exhaustion, 29 BERKELEY TECH. L.J. 1535, 1539 (2014).

7 Id. at $1539-44$
} 
core functions address endemic market failures that will continue to persist even if most content were digitized. Therefore, the erosion of the first-sale doctrine may not result in new business models that better serve the public while remunerating authors, but may instead result in a net loss for all.

The paper begins with a historical reminder: libraries and universities predate copyright. In Part I, I note that the institutional role of libraries and institutions of higher learning in the "promotion of science" and the "encouragement of learning" was acknowledged even before the first copyright statutes were enacted. This history is important for charting the future direction of copyright law because it constitutes part of the context in which copyright law was born and it helps illuminate the goals copyright was created to achieve. In Part II, I establish the plausibility of digital exhaustion. I explain why the first-sale doctrine is only one manifestation of a broader principle of exhaustion, which is not necessarily limited to the distribution right and is capable of broader application. In Part III, I explain why not all licensing or contractual restrictions on downstream uses are enforceable. In Part IV, I show how the social functions of libraries justify the development of the law in the direction argued for below.

\section{LIBRARIES PREDATE COPYRIGHT}

Libraries and universities predate copyright. The institutional role of libraries and institutions of higher learning in the "promotion of science" and the "encouragement of learning" was acknowledged before legislators decided to grant authors exclusive rights in their writings. Beginning in the sixteenth century, the universities of Cambridge and Oxford (the only two English universities at the time) were entrusted "with the special privilege and authority of printing within their respective Universities, and of selling or causing to be sold throughout his Majesty's dominions or elsewhere all manner of books and works of whatever description, not prohibited by public authority, and whether the same may be or not contained or mentioned in any other Royal Charter or Grant to any other Printer". ${ }^{8}$ Not only were universities permitted to print and sell books regardless of any exclusive rights granted to others, ${ }^{9}$ but subsequent legislation also required publishers to deliver the best quality copies of every

\footnotetext{
${ }^{8}$ The Universities of Oxford \& Cambridge v. Richardson, 31 ER 1260 (1802).

9 DAVID MCKITTERICK, A History OF CAMBRIDGE UNIVERSity PRESS xii (1992).
} 
newly printed or reprinted book for the use of the public libraries of the universities. ${ }^{10}$

Moreover, when the Statute of Anne, the first copyright act, was enacted in 1709, it included both a provision clarifying that it did not affect any right that the universities have had, or could claim to have, to the printing or reprinting of any book, ${ }^{11}$ and an expanded duty to deliver books to the libraries of the universities and other institutions in England and Scotland.12 The act also established a mechanism to control the prices of books if found to be "too high and unreasonable", and it included the vice chancellors of the two universities among the group of public officials that could set the maximum price for which a book could be sold. ${ }^{13}$ In Cambridge University $v$. Bryer, the court

\begin{abstract}
${ }^{10}$ See, e.g., Licensing Act, 1662, 5 Statutes of the Realm 428 1625-1680 (An Act for preventing the frequent Abuses in printing seditious treasonable and unlicensed Books and Pamphlets and for regulating of Printing and Printing Presses, 13 \& 14 Car. 2, e. 33, ss. 16, 17 (1662)).

${ }^{11}$ Statute of Anne, s IX ("Provided, that nothing in this act contained shall extend, or be construed to extend, either to prejudice or confirm any right that the said universities, or any of them, or any person or persons have, or claim to have, to the printing or reprinting any book or copy already printed, or hereafter to be printed.”).
\end{abstract}

${ }^{12}$ Statute of Anne, s V ("[A]nd it is hereby enacted, that nine copies of each book or books, upon the best paper ... shall, by the printer and printers thereof, be delivered ... for the use of the royal library, the libraries of the universities of Oxford and Cambridge, the libraries of the four universities in Scotland, the library of Sion College in London, and the library commonly called the library belonging to the faculty of advocates at Edinburgh respectively... ”).

${ }^{13}$ Statute of Anne, s IV ("if any bookseller or booksellers, printer or printers, shall ... set a price upon, or sell, or expose to sale, any book or books at such a price or rate as shall be conceived by any person or persons to be too high and unreasonable; it shall and may be lawful for any person or persons, to make complaint thereof to the lord archbishop of Canterbury for the time being, the lord chancellor, or lord keeper of the great seal of Great Britain for the time being, the lord bishop of London for the time being, the lord chief justice of the court of Queen's Bench, the lord chief justice of the court of Common Pleas, the lord chief baron of the court of Exchequer for the time being, the vice chancellors of the two universities for the time being, ... who, or any one of them, shall and have hereby full power and authority, from time to time, to send for, summon, or call before him or them such bookseller or booksellers, printer or printers, and to examine and enquire of the reason of the dearness and inhauncement of the price or value of such book or books by him or them so sold or exposed to sale; and if upon such enquiry and examination it shall be found, that the price of such book or books is inhaunced, or any wise too high or unreasonable, then and in such case the said [officials], or any one or more of them, so enquiring and examining, have hereby full power and authority to reform and redress the same, and to limit and settle the price of every such printed book and books, from time to time, according to the best of their judgments, and as to them shall seem just and reasonable..."). 
explained that both measures demonstrated the legislature's intent to encourage learning by facilitating access to books. Price controls aimed to ensure the accessibility of literature to persons desirous of purchasing books, and mandatory library deposit of books enabled literary persons to access books even if they may not be able to afford purchasing them. ${ }^{14}$

While today's copyright statutes no longer contain these exact statutory provisions, this history is nonetheless important. First, because it constitutes part of the context in which copyright law was born and it helps illuminate the goals it was created to achieve.15 The public interest in gaining access to works has always been the main goal of copyright law, ${ }^{16}$ even if the means to achieve this goal might change over time.

Second, as the case law discussed in the next Parts affirms, the copyright statute should not be interpreted as if it were written on a legal clean slate, but against the backdrop of previously existing or recognized rights and interests. Just as the statute presumably retains the substance of the common law rights of individuals, ${ }^{17}$ it should also presumably preserve the ability of public institutions to pursue their recognized mandate, unless there is a clear indication of legislative intent to the contrary. ${ }^{18}$

Third, in countries such as Canada or the United States, this history might also affect the ability of federal legislation to enact copyright laws that impact the ability of libraries and educational institutions to pursue their mandates. While the Constitutions of both countries empower the federal legislature to enact copyright laws, principles of federalism limit the extent of these powers inasmuch as

\footnotetext{
14 Univ. of Cambridge v. Bryer, 16 ER 317, 321 (1812).

${ }^{15} I d$. (noting that even though the specific price-setting provision had been repealed, it was part of an entire Act, which shows that and facilitating access to works was one of the objectives of the legislation).

${ }^{16}$ See, e.g., Feist Pubs., Inc. v. Rural Tel. Svc. Co., Inc., 499 U.S. 340, 349 (1991) ("The primary objective of copyright is not to reward the labor of authors, but to promote the Progress of Science and useful Arts.”).

${ }_{17}$ Kirtsaeng v. John Wiley \& Sons, Inc., 133 S. Ct. 1351, 1353 (2013).

${ }^{18}$ Id. at 1374.
} 
they intrude into subject matter that falls within provincial or state jurisdiction. ${ }^{19}$

None of these considerations, of course, can directly determine the question of digital exhaustion-after all, one could search the law books in vain and would not find any case law predating the copyright statutes that explicitly recognizes a right to reproduce digital copies of books in order to transfer them to others. At the same time, however, one would equally fail to find a common law right to prohibit such reproductions, because there was no common law right to prohibit the reproduction of books at all. Ultimately, the question is whether the existing copyright statute prohibits such reproductions, and in answering this question history and the common law base lines could matter.

But even if these considerations seem to offer only a limited doctrinal utility, they still carry considerable moral and rhetorical force. They remind librarians that the various acts that constitute "librarying" are not mere legal crumbs they were permitted to collect to the extent they fell off the copyright table. Rather, they reiterate that copyright law was never intended to hinder librarying, and that the public interest in the various social and cultural interactions that libraries facilitate was preserved and etched into the copyright system from its very beginning.

This history, combined with the line of exhaustion cases, discussed below, teaches that the interpretative task in construing the scope of owners' exclusive rights ought, among other things, to consider whether, to the extent that a copyright owner's proffered interpretation interferes with the freedoms of libraries and their patrons, the legislature intended to impose such a limitation. In a similar vein, the Supreme Court of Canada recently held that the traditional balance between authors and users should be preserved in the digital environment, and that, absent evidence of legislative intent to the contrary, courts should interpret the Copyright Act "in a way that avoids imposing an additional layer of protections and fees based

\footnotetext{
19 In Canada, for example, laws in relation to "property and civil rights", or "education" fall under exclusive provincial jurisdiction. Thus, copyright legislation that unduly restricts what people can do with objects or devices that embody works of authorship (or how educational institutions carry out their mandate) might be unconstitutional. See, e.g., Jeremy F. de Beer, Copyrights, Federalism, and the Constitutionality of Canada's Private Copying Levy, 51 MCGILL L.J. 735 (2005-2006) (discussing "property and civil rights"); Ariel Katz, Spectre: Canadian Copyright and the Mandatory Tariff - Part II, 28 IPJ 39, 92-93 (2015) (discussing "education").
} 
solely on the method of delivery of the work to the end user. To do otherwise would effectively impose a gratuitous cost for the use of more efficient, Internet-based technologies." 20

These principles of statutory interpretation do not immediately solve the question of digital exhaustion, but they do clarify the baselines for the debate and the burdens of proof: libraries do not need to prove that the current copyright legislation intended to allow them to continue pursuing their mandate in the digital realm. Rather, copyright owners have to prove that the legislature intended to prevent libraries from so doing. To the extent that a broad construction of the reproduction or distribution rights (and a corresponding narrow construction of the first-sale doctrine) diminish the capacity of libraries to pursue their public mandate, and adapt it to the digital realities, these principles provide a juridical basis for rejecting such a construction.

\section{The Plausibility of Digital Exhaustion}

\section{A. Kirtsaeng v. John Wiley \& Sons: Life Beyond s 109(a)}

In Capitol Records v. ReDigi, ${ }^{21}$ the U.S. District Court for the Southern District of New York adopted the view that the first-sale doctrine would not apply whenever the resale of a work in digital format requires a reproduction of the work. The holding had two prongs: first,that transferring a digital file from one medium to another constitutes a reproduction within the meaning of the Copyright Act, even if there is no multiplication of copies; ${ }^{22}$ second, that the first-sale doctrine affords protection only against assertions of the distribution right but not against violation of other rights. ${ }^{23}$ The court also declined to entertain any interpretation of the Act that could allow digital first-sale. It held that the Act unambiguously precludes any such outcome, and concluded that an alternative interpretation would amount to an amendment of the Copyright Act,

\footnotetext{
${ }^{20}$ Entm't Software Ass'n v. Soc'y of Composers, Authors \& Music Publishers of Canada, [2012] 2 S.C.R. 231 ๆ ๆ 8-9 (Can.).

${ }^{21}$ Capitol Records, LLC v. ReDigi Inc., 934 F. Supp. $2 d 640$ (S.D.N.Y. 2013).

${ }^{22} I d$. at 648 .

${ }^{23} \mathrm{Id}$. at 655 .
} 
which is "a legislative prerogative that courts are unauthorized and ill suited to attempt."24

Yet, eleven days before the court handed down its decision in ReDigi, the Supreme Court decided Kirtsaeng, which casts doubt on the District Court's unequivocal decision. Kirtsaeng did not involve digital exhaustion. The question before the Court in that case was whether the first-sale doctrine applied to copies made abroad and imported into the United States without the consent of the copyright owner. The majority held that it did, and their reasons are relevant to digital exhaustion as well. The majority, per Justice Breyer, emphasized that the first-sale doctrine does not owe its origin to the statute, and that Section 109 (and its predecessor in Copyright Act of 1909) merely codifies the common law refusal to permit restraints on alienation, which harkens back at least to the early 17th century. ${ }^{25}$ This recognition, combined with the presumption that unless the contrary is evident " [s]tatutes which invade the common law...are to be read with a presumption favoring the retention of long-established and familiar principles," ${ }^{26}$ led the majority to reject an interpretation that would limit the scope of the first-sale doctrine to copies made in the United States. ${ }^{27}$ Likewise, Justice Kagan, in her concurring opinion, emphasized that the doctrine has played an integral part in American copyright law even prior to its codification. ${ }^{28}$

Justice Ginsburg's dissent is equally instructive. She did not disagree with the majority's general characterization of the doctrine and its non-statutory origin, and explained that the doctrine "recognizes that a copyright owner should not be permitted to exercise perpetual control over the distribution of copies of a copyrighted work." 29 Nevertheless, she was convinced that in 1976 Congress intended to exclude copies made abroad from the ambit of Section

\footnotetext{
${ }^{24} I d$.

25 Kirtsaeng v. John Wiley \& Sons, Inc., 133 S. Ct. 1351, 1361-63 (2013).

${ }^{26}$ Id. at 1363 (quoting Isbrandtsen Co. v. Johnson, 343 U.S. 779, 783 (1952) (omission by the Court)).

${ }^{27}$ For a survey of earlier cases applying exhaustion principles in the U.S., see Aaron Perzanowski \& Jason Schultz, Digital Exhaustion, 58 UCLA L. REV. 889, 912-22 (2011).

${ }^{28}$ Kirtsaeng, 133 S. Ct. at 1372 (Kagan, J., concurring).

${ }^{29}$ Id. at 1374 (Ginsburg, J., dissenting).
} 
109(a). She concluded, however, that the first-sale doctrine would still apply to such copies after the copyright holder authorized their importation. Even though she could not anchor this proposition in the statutory language, she reasoned, based on the statutory history, that the term "distribute" in Section 106(3) already incorporates the firstsale doctrine. Acknowledging that this interpretation means Section 109(a)'s codification of that doctrine adds little to the regulatory regime, she insisted that the section is not redundant, because it prevents courts from deviating from the doctrine in a way that increases copyright owners' control over downstream distribution ${ }^{30}$ and in some specific instances even expands the doctrine's scope. ${ }^{31}$ Therefore, even though the doctrine's application to the importation of copies made abroad divided the Court, it appears (practically) unanimous that the first-sale doctrine has life beyond the words of Section 109(a)..$^{2}$

Kirtsaeng affirmed that the basis of the first-sale doctrine is not statutory. The upshot of the opinions of both Breyer and Ginsburg is that people can resell, lend, or give away lawfully made books - not because Congress created a limited exception to the copyright owner's distribution right, but because Congress had never intended to allow copyright owners the power to do so.

Justice Ginsburg wrote that it was appropriate for the Court in Bobbs-Merrill v. Straus (the 1908 case articulating the first-sale doctrine), to hold that "Congress did not intend to permit copyright owners 'to fasten ... a restriction upon the subsequent alienation of

\footnotetext{
${ }^{30} \mathrm{Id}$. at 1387 (Ginsburg, J., dissenting).

${ }^{31} \mathrm{Id}$. at $1387 \mathrm{n} .20$. Section 109 expands the scope of exhaustion beyond that recognized in Bobbs-Merrill Co. v. Straus, 210 U.S. 339 (1908). Bobbs-Merrill held that the copyright owner could not control sales beyond the first authorized sale. Id. at 350-51. Section 109, however, makes it lawful for the owner of a lawfully made copy to resell it, regardless of whether a previous authorized sale had taken place. See John A. Rothchild, Exhaustion of Intellectual Property Rights and the Principle of Territoriality in the United States, in RESEARCH HANDBOOK ON INTELLECTUAL PROPERTY EXHAUSTION AND PARALLEL IMPORTS 226, 228 n.4 (Irene Calboli \& Edward Lee eds., 2016).
}

${ }^{32}$ I say "practically unanimous" because Justice Scalia joined Justice Ginsburg's dissent, but did not join this part of her decision. He did not, however, provide any reasons explaining his disagreement. Justice Ginsburg's interpretation explicitly resorted to the doctrine's pre-codified form in order to give the doctrine meaning not anchored in the codifying text, and the opinions of Justice Breyer and Justice Kagan are not inconsistent with this view. 
the subject-matter of copyright"' 33 even though the statute then did not include any such explicit limitation. Consequently, it would have been legitimate for the court in ReDigi to do the same.

The line of patent exhaustion cases following Bobbs-Merrill supports the conclusion that the first-sale doctrine is only a species of a broader principle of exhaustion, and, as such, it is not necessarily limited to the distribution right. In Henry v. A.B. Dick Co.,34 the Court declined to extend the holding of Bobbs-Merrill to patent law, emphasizing that Bobbs-Merrill dealt only with a copyright owner's exclusive right to "vend", not with a patentee's exclusive right to "use" the invention. 35 But five years later, in Motion Picture Patents $v$. Universal, the Court reversed Henry and held that the sale of a machine embedding a patented invention exhausts that patent owner's exclusive right to "use" the invention, just as it exhausts the exclusive right to "vend" it. ${ }^{6}$ Indeed, the fact that Congress has never codified the principle of exhaustion in patent law provides additional evidence that the source of the doctrine is not statutory. ${ }^{37}$

The significance of Kirtsaeng (and the line of previous exhaustion cases) lies in clarifying the baseline for understanding the scope of exhaustion as developed by the Court's jurisprudence: copyright owners' exclusive rights are a creature of statute, but users' liberty of transferring ownership or possession of copies of books to others is not. Users can exercise this liberty not because Congress has chosen to exempt it from what otherwise would be prohibited, but because it never intended to limit it in the first place. These holdings reflect an established legal principle: Under the common law, every person is free to dispose of their possessions or carry on their business as they please in the absence of positive law limiting those freedoms. The legislature could limit those freedoms, but courts should not construe statutes to have such a limiting effect, unless the legislature has communicated its intent to depart from common law principles with

\footnotetext{
33 Kirtsaeng, 133 S. Ct. at 1386 (quoting Bobbs-Merrill Co., 210 U.S. at 349-50).

34 Henry v. A.B. Dick Co., 224 U.S. 1 (1912).

$35 \mathrm{Id}$. at 46 .

${ }^{36}$ Motion Picture Patents Co. v. Universal Film Co., 243 U.S. 502, 516 (1917).

37 While it could be argued that this is no longer true with respect to copyright, where Congress codified the doctrine, Kirtsaeng, as discussed above would not support this proposition.
} 
irresistible clarity,,$^{8}$ and statutory grants that derogate from the common law rights of others ought to be construed narrowly. 39

\section{B. Exhaustion Beyond Distribution}

Exhaustion's death prognosis rests on the proposition that the first-sale doctrine limits only the scope of the distribution right and therefore becomes inapplicable the moment that a transfer of a work in a digital format requires its reproduction. Accepting this premise, the defendant in ReDigi developed technology that allegedly permitted users to transfer digital files without multiplying them, arguing that reproduction occurs only if copies are being multiplied. The District Court rejected that view and held that reproduction occurs whenever a work is embedded in a new material object, regardless of whether additional copies were made or not. $4^{4}$

The Disctrict Court's interpretation is questionable. It ignored dicta of the Supreme Court referring to the reproduction right as the right to multiply copies, ${ }^{41}$ and it refused to follow an earlier case, by another district court, involving transfer of ink from one medium to another where the court held that no reproduction occurred in the absence of multiplication. $4^{2}$ Instructively, the Supreme Court of Canada held that reproduction indeed requires multiplication of

\footnotetext{
${ }^{88}$ Goodyear Tire \& Rubber Co. of Canada v. T. Eaton Co., [1956] S.C.R. 610 (Can.); United States v. Texas, 507 U.S. 529, 534 (1993).

39 See, e.g., THEOdore SEDGWICK, A TREATISE ON THE RULES Which GOVERn THE INTERPRETATION AND CONSTRUCTION OF STATUTORY AND CONSTITUTIONAL LAW 291-92 (John Norton Pomeroy ed., 2d ed. 1874). See also Ariel Katz, Intellectual Property, Antitrust, and the Rule of Law: Between Private Power and State Power, 17 THEORETICAL INQUIRIES L. 633 (2016).

${ }^{40}$ Capitol Records, LLC v. ReDigi Inc., 934 F. Supp. 2d 640, 640 (S.D.N.Y. 2013).

${ }^{41}$ See, e.g., Stephens v. Cady, 55 U.S. 528, 530-31 (1852); Bobbs-Merrill Co. v. Straus, 210 U.S. 339 (1998); Globe Newspaper Co. v. Walker, 210 U.S. 356, 362 (1908); Bong v. Alfred S. Campbell Art Co., 214 U.S. 236, 246 (1909); Caliga v. Inter Ocean Newspaper Co., 215 U.S. 182 (1909); Henry v. A.B. Dick Co., 224 U.S. 1, 46 (1912); Fox Film Corp. v. Doyal, 286 U.S. 123, 127 (1932).
}

${ }^{42}$ ReDigi Inc., 934 F. Supp. 2 d at 650 (discussing C.M. Paula Co. v. Logan, 355 F. Supp. 189, 190 (N.D. Tex. 1973). 
copies, not merely new fixation, relying, among other things, on the same American case that the court in ReDigi rejected. 43

Nevertheless, the premise that reproduction necessarily renders the first-sale doctrine inapplicable is false, because it presupposes that when Congress codified the doctrine articulated in Bobbs-Merrill it intended to confine the principle to the distribution right and preclude its application to other rights. Without a clear indication that this was Congress' intent, it is open for the courts to apply the principle of exhaustion to the various exclusive rights in the copyright bundle, not only to the distribution right. Therefore, the principle may encompass situations where reproduction is incidental to the transfer of a digital file.

The evolution of exhaustion in patent law illustrates the point. In Henry v. A.B. Dick Co., a divided U.S. Supreme Court had initially declined to apply its copyright exhaustion holding from Bobbs-Merrill in the area of patent law, emphasizing the differences between the statutes.44 But this holding was short lived. The following year, the Court held that the exclusive right to vend had the same meaning under the patent and the copyright statutes, and that the scope of the right was the same; if the sale of a book exhausts the exclusive right to vend it, so does the sale of a patented machine. ${ }^{45}$ Shortly thereafter, the Court overruled Henry and applied the exhaustion principle not only to the exclusive right to "vend" the patented article, but also to the right to "use" it. 46 Taken together, those decisions support the following propositions: (a) there are no major differences between the exhaustion of copyrights and the exhaustion of patents; (b) exhaustion of a patent is not limited to the right to sell it; (c) therefore, exhaustion

${ }^{43}$ See Théberge v. Galerie d'Art du Petit Champlain Inc., [2002] 2 S.C.R. 336 (Can.) (the dissent interpreted the reproduction right exactly as the court in ReDigi did).

44 Henry, 224 U.S. at 46 (explaining that while the copyright statute only grants an
exclusive right to multiply and sell, the patent statute provides more extensive rights "to
make, use, and vend the invention or discovery."). Notably, when Henry was decided,
Congress had already codified the first-sale doctrine in the Copyright Act of 1909, but the
fact that Congress only codified the exhaustion of the copyright owner's right to vend, but
not other rights, let alone any of the exclusive rights of patentees, played no role in the
majority opinion.

45 Bauer \& Cie v. O'Donnell, 229 U.S. 1, 17-18 (1912). As noted in note 44 with respect to Henry, the fact that exhaustion of the vending right under copyright law had been codified but Congress had not codified any of the rights of patentees also played no part in this case.

${ }^{46}$ Motion Picture Patents Co. v. Universal Film Co., 243 U.S. 502, 516 (1917). 
of copyright may also not be limited to the distribution right. The codified "first sale" doctrine may be limited to the distribution right, but the un-codified principle of exhaustion, of which it is only a subset, is not so limited.

Moreover, as Perzanowski and Schultz demonstrate, American courts have applied the principle of exhaustion more broadly than as a limitation on the distribution right, 47 and as I discuss elsewhere, the logic of exhaustion has animated various Canadian copyright decisions that narrowed the construction of the reproduction and public performance rights, respectively. 48

The most recent patent exhaustion case from the U.S. Supreme Court, Bowman v. Monsanto, ${ }^{49}$ may help draw some of the limitations on the broad application of the exhaustion principle. In that case, the Court held that the exhaustion doctrine in patent law does not permit a farmer to reproduce patented seeds through planting and harvesting without the patent holder's permission. The Court distinguished this case from other exhaustion cases on the grounds that it involved multiplication and replication of the patented item, and not merely its reuse. At the same time, the Court emphasized that the ruling does not imply a broader rule whereby multiplication would necessarily negate exhaustion, giving, as an example, instances where reproduction is a necessary but incidental step in using the item for another lawful purpose..$^{\circ}$ In the case at hand, the defendant could not rely on exhaustion because he planted patented soybeans solely to make and market replicas of them, thus depriving the company of the reward patent law provides for the sale of each article.

The same logic can apply to distinguish between situations where reproduction is merely a necessary and incidental step in the transfer of a digital copy of a work from one user to another-where exhaustion should apply-from instances where a user who purchases a single copy reproduces and distributes multiple copies in a way that directly competes with the sale of additional copies by the copyright

\footnotetext{
47 Perzanowski \& Schultz, supra note 27, at 912-22.

${ }^{48} \mathrm{Katz}$, supra note 5, at 152-56.

49 Bowman v. Monsanto, 133 S. Ct. 1761 (2013).
}

$5^{\circ} \mathrm{Id}$. at 1769 (referring to 17 U.S.C. $§ 117$ (a)(1) ("[I]t is not [a copyright] infringement for the owner of a copy of a computer program to make ... another copy or adaptation of that computer program provide[d] that such a new copy or adaptation is created as an essential step in the utilization of the computer program")). 
owner. In the first case, the incidental reproduction does not change the quantity of copies that are available in the market and can be enjoyed at any particular time-the quantum of simultaneous uses remains entirely dependent on the number of copies that the copyright owner has chosen to sell. Conversely, in the second case, the reproduction increases the number of such copies beyond the quantum chosen by the copyright owner.

In sum, the first prong of the death prognosis-the premise that there can be no digital exhaustion because the transfer of digital file involves their reproduction-is false. The principle of exhaustion can be applied, and has been applied, broadly and is not limited to the distribution right.

\section{THE LIMITS OF PRIVATE REORDERING}

\section{A. Exhaustion: Limits on Contract and License Override}

The premise that license restrictions and contracts can override exhaustion constitutes the second prong of the death prognosis of the first-sale doctrine. Those who take this premise for granted do it at their own peril, because principle and legal precedent suggest otherwise. Over a period of ten years, beginning with Bobbs-Merrill in 1908 and ending with Boston Store in 1918, the same Court decisions that established the doctrine of exhaustion also restricted the ability of IP owners to evade it using various techniques, including notices, license restrictions, and contracts.

With respect to notices, Bobbs-Merrill made it clear that copyright owners cannot restrict the rights of buyers and expand the scope of their own rights by merely printing a notice in the book. ${ }^{51}$ It might seem straightforward that if a copyright owner lacks the power to control sales beyond the first authorized sale, it cannot assume this power by the mere act of posting a notice, but when the Court decided Bobbs-Merrill, the competing view seemed at least as plausible. Indeed, the same year the U.S. Supreme Court decided Bobbs-Merrill, the High Court of Australia was divided on the question of whether a patentee's exclusive right to "vend" the patented article conferred upon it the power to maintain the resale price of the patented

${ }^{51}$ Bobbs-Merrill Co. v. Straus, 210 U.S. 339, 350 (1908). 
articles. ${ }^{52}$ The majority opinion in Nat'l Phonograph Co. of Austl. $v$. Menck was remarkably similar to that of the U.S. Supreme Court in Bobbs-Merrill. However, on appeal, the Privy Council reversed and decided that "the general doctrine of absolute freedom of disposal of chattels of an ordinary kind is, in the case of patented goods, restricted when the patentee attaches conditions which the buyer becomes aware of at the time of sale." 53 The scope of exhaustion, under that view, depended entirely on the IP owner's preferences. In the absence of an indication to the contrary, the patentee is presumed to have exhausted her right, but the right of buyers to dispose of what they had purchased could be taken away by mere notice of the patentee's intention to restrict it. Any person having notice of such restrictions could be liable for infringing the patent if she violates them.

The majority of the U.S. Supreme Court in Henry followed the Privy Council decision in Menck. ${ }^{54}$ But shortly thereafter the Court overruled Henry in the concurrently decided cases of Motion Picture Patents and Straus v. Victor Talking Machine Co.55 In those cases, the Court held that the rights of a patentee under the patent statute did not include the power to impose restrictions on the use of a patented machine through license agreements or license notices. The Court, in these two decisions, also rejected the patentees' attempts to avoid the consequences of exhaustion by describing the transactions they entered into with users not as "sales" of the patented machines, but as leases or licenses to use them..$^{6}$

The logic that animates the premise that license restrictions can override exhaustion is eerily similar to the logic that patentees promoted a hundred years ago. Back then, patentees claimed that since they had an exclusive right to "use" the invention, any use required their permission. This, in turn, enabled them to grant permission subject to conditions that allowed them to exercise

\footnotetext{
$5^{2}$ Nat'l Phonograph Co. of Austl. v. Menck (1908) 7 C.L.R. 481, rev'd, Nat'l Phonograph Co. of Austl. v. Menck (1911) 12 C.L.R. 15 (PC) (appeal taken from Austl.).

53 Nat'l Phonograph Co. of Austl., 12 C.L.R. at 21, 24.

54 Henry v. A.B. Dick Co., 224 U.S. 1, 1, 42-43, 49 (1912).

55 Motion Picture Patents Co. v. Universal Film Co., 243 U.S. 502, 515 (1917); Straus v. Victor Talking Machine Co., 243 U.S. 490, 501 (1917).

${ }^{6} \mathrm{Id}$
} 
ongoing control over how devices that embodied their inventions could be used, even after they parted with them. 57 They also argued that they could maintain control over the use of the machines they sold by describing the transactions as leases or licenses rather than sales. ${ }^{8}$ Today, copyright owners advance a similar logic by arguing that downloading or installing a digital file requires a license, 59 and that describing these transactions as licenses rather than sales, overcomes exhaustion. ${ }^{60}$ Because they have no obligation to grant anyone license, and can refuse to grant one altogether, it must follow, pursuant to this logic, that they are entitled to grant restrictive licenses, including those that prohibit users from doing otherwise permissible activities. However, the Court rejected that logic and lower courts should decline the invitation to apply it.

In sum, by 1917, the Court affirmed conclusively that the IP statutes did not confer upon the owners of patents and copyrights the power to control how the products embodying their inventions or works could be used or resold after they parted with them. Therefore, they could not arrogate to themselves such powers by purporting to reserve them through licensing restrictions. The Court emphatically rejected the notion that exhaustion was no more than a default rule that IP owners could reverse by providing notice of their intent to restrict it. Rather, the Court understood exhaustion as an integral component of the general legal order, which Congress did not intend to modify, and which IP owners were incapable of altering. ${ }^{61}$

The plaintiffs in this line of cases alleged that when the various defendants violated the restrictive terms they purported to impose on users, these defendants were liable for copyright or patent

\footnotetext{
57 See, e.g., Motion Picture Patents Co., 243 U.S. at 519 (Holmes, J., dissenting: “I suppose that a patentee has no less property in his patented machine than any other owner, and that in addition to keeping the machine to himself the patent gives him the further right to forbid the rest of the world from making others like it. In short, for whatever motive, he may keep his device wholly out of use ... So much being undisputed, I cannot understand why he may not keep it out of use unless the licensee, or, for the matter of that, the buyer, will use some unpatented thing in connection with it." Internal citation omitted).
}

${ }^{8}$ Id. at 515; Straus, 243 U.S. at 501.

59 And under some views even executing it. See MAI Sys. Corp. v. Peak Computer, Inc., 991 F.2d 511 (9th Cir. 1993).

${ }^{60}$ See, e.g., Vernor v. Autodesk, Inc., 621 F.3d 1102 (9th Cir. 2010).

${ }^{61}$ See Katz, supra note 39, at 681. 
infringement. The defendants prevailed in those cases because the Court held that the IP statutes did not confer the power to restrain the defendants from the acts complained about. Since the defendants did not infringe the IP rights, the plaintiffs were not entitled to any remedy that otherwise could be available to them had the IP rights been infringed. Therefore, these cases did not answer the question of whether contracts that contain the same or similar restriction could be relied on to limit exhaustion. In fact, in Bobbs-Merrill the Court noted there was no contract claim before it ${ }^{62}$ and emphasized that it was only dealing with the question of whether the copyright statute conferred the power to restrict subsequent sales and not with whether a contract restricting the same would be enforceable. ${ }^{63}$

This, according to some, indicates that nothing in the Court's jurisprudence supports the proposition that contractual restrictions on exhaustion will not be enforceable- implying that as long as the contract is otherwise valid, courts will enforce the restrictions. ${ }^{64}$ However, in reality one can infer very little from the Court's unsurprising failure to decide an issue that was not properly before it.65 The Court's subsequent decisions provide more than solid indications that while some contractual limitations might be valid, others would not. ${ }^{66}$

Three years after Bobbs-Merrill, the Court in Dr. Miles Medical Co. v. John D. Park \& Sons Co. ${ }^{67}$ held that contracts to maintain the resale price of proprietary medicines were invalid both at common law as unreasonable restraint of trade, and also under the Sherman Act. ${ }^{68}$ The following year, the majority in the short-lived Henry v. A.B. Dick case held that Dr. Miles was inapplicable to the sale of patented

\footnotetext{
${ }^{62}$ Bobbs-Merrill Co. v. Straus, 210 U.S. 339, 346 (1908).

${ }^{63} \mathrm{Id}$. at 350 .

${ }^{64}$ See, e.g., John F. Duffy \& Richard M. Hynes, Statutory Domain and the Commercial Law of Intellectual Property, 102 VA. L. REV. 1, 10 (2016).

${ }_{55}$ Ariel Katz, Aaron Perzanowski \& Guy A. Rub, The Interaction of Exhaustion and the General Law: A Reply to Duffy and Hynes, 102 VA. L. REV. ONLINE 8, 15 (2016).

${ }^{66} \mathrm{Katz}$, supra note 39 , at 695-96.

${ }_{67}$ Dr. Miles Med. Co. v. John D. Park \& Sons Co., 220 U.S. 373 (1911).

${ }^{68} \mathrm{Id}$. at 409.
} 
goods. ${ }^{69}$ However, as noted, the Henry decision was short lived, and the vigorous dissent written by Chief Justice White became the view of the majority five years later. ${ }^{70}$ A year later in Boston Store of Chicago $v$. American Graphophone Co. ${ }^{71}$ the Court discarded any remaining doubts that the general common law rules regarding contractual restraints on trade apply to the sale of patented articles or copyrighted works in the same way as they apply to other chattels. ${ }^{72}$

Dr. Miles in subsequent years stood for the proposition that resale price maintenance constituted a per se antitrust violation: that is, a practice categorically prohibited, without inquiry into its actual effect on competition. In 2007, the Court overruled this aspect of that decision.73 However, the more general propositions that contracts purporting to exert downstream control over the sale or use of goods could be invalid at common law as unreasonable restraint of trade, and that the grant of a patent or copyright does not include the power to make contracts in derogation of that general law, remain valid.74 Thus, the Court held that as a matter of federal antitrust law a restrictive contract will not attract antitrust liability unless it has been proven to restrain competition in a relevant market, but the contract may still be invalidated as unreasonable restraint of trade under the law of the relevant state. ${ }^{75}$

\section{B. Towards a Digital Restraint of Trade Doctrine}

Noting that contracts attempting to limit exhaustion could be invalidated under the common law doctrine of restraint of trade does not imply, of course, that all such contracts would be invalid. The key question is whether the restraint is reasonable.

\footnotetext{
${ }^{69}$ Henry v. A.B. Dick Co., 224 U.S. 1, 49 (1912).

${ }^{70}$ See supra Part II(B).

${ }^{71}$ Bos. Store of Chi. v. Am. Graphophone Co., 246 U.S. 8 (1918).

${ }^{72} \mathrm{Id}$. at 25 .

73 Leegin Creative Leather Products v. PSKS, Inc., 551 U.S. 877 (2007).

74 Katz, supra note 39, at 693.

${ }^{75} C f$. Erie R.R. Co. v. Tompkins, 304 U.S. 64 (1938).
} 
Generally, a reasonable restraint would be one that is merely ancillary to an otherwise legitimate contract and where it is "inserted only to protect one of the parties from the injury which, in the execution of the contract or enjoyment of its fruits, he may suffer from the unrestrained competition of the other." 76 If the restraint is not necessary for achieving the goal of the contract, or if it exceeds what is necessary to achieve that goal, it is void. 77 Moreover, even if the restraint is no greater than is needed to protect the promisee's interest, it might still be void if the harm to the promisor and the likely injury to the public outweigh the need of the promisee..$^{8}$

Like the first-sale doctrine itself, which the Court described as "a common law doctrine with impeccable historic pedigree",79 the aversion to contracts in restraint of trade is one of the common law's oldest and best-established doctrines. ${ }^{80}$ As a venerable common law rule, the doctrine of restraint of trade provides a heft of legal history along with flexibility and capacity to adapt to the realities of the digital realm. It also provides a useful framework for distinguishing situations where contractual limitations on exhaustion could be justified from those where they would not. Providing a thorough analysis of various contractual restraints and their validity would go beyond the scope of this essay (and post Erie Railroad Co. $v$. Tompkins ${ }^{81}$ the question might have to be decided as a matter of state law rather than federal law), but a few examples could illustrate the direction.

Supporters of narrow exhaustion rules (and of extended freedom to contract around them) often argue that allowing copyright owners to control the downstream use of their works would allow them to set different prices for different users. Without the power to price discriminate, they argue, the copyright owner might elect to set a high uniform price, resulting in a lower quantity of distributed copies and

\footnotetext{
${ }^{76}$ U.S. v. Addyston Pipe \& Steel Co., 85 F. 271, 282 (6th Cir 1898).

$77 \mathrm{Id}$.

78 RESTATEMENT (SECOND) OF CONTRACTS § 188 (1981).

79 Kirtsaeng v. John Wiley \& Sons, Inc., 133 S. Ct. 1351, 1363 (2013).

80 RESTATEMENT (SECOND) OF CONTRACTS CHAPTER 8 INTRO. NOTE (1981).

${ }^{81}$ Erie R.R. Co. v. Tompkins, 304 U.S. 64 (1938).
} 
the exclusion of consumers with a lower willingness or ability to pay. ${ }^{82}$ If so, then greater control over downstream uses could be efficient; efficient both in the static sense of reducing the deadweight loss that may result from the grant of copyright, as well as efficient in the dynamic sense of allowing copyright owners to earn a higher profit, potentially increasing the incentive to create (even without improving static efficiency). ${ }^{83}$

Elsewhere, I have discussed why the economics of price discrimination are more complicated than the above account: its benefits are not as straightforward, and exhaustion does not seriously threaten these benefits, when they exist. ${ }^{84}$ Even if copyright law does not allow publishers to control the resale of digital copies, publishers have options. They can still sell digital copies subject to reasonable post-sale contractual "sticks" to discourage resale, or offer "carrots" to induce the retention of copies if the speed and ease of digital resale proves detrimental. ${ }^{85}$ As long as (i) publishers' inability to control any downstream use proves detrimental to the incentivizing goals of copyright law, (ii) they adopt limited contractual restraints that are narrowly tailored to counter this detrimental effect, and (iii) those restraints do not impose a greater harm on the access and dissemination goals of copyright law and on the freedoms of users, such contractual restraints could be held valid. At the same time, it is easy to see how restraints that are neither limited in time or scope, nor otherwise tailored narrowly to address a specific legitimate purpose, can do more harm than good, and should be invalidated.

Opponents of digital exhaustion also argue that unlike used tangible copies that ordinarily wear out through use and repeated transfers from one user to another, digital copies remain pristine and perfect substitutes for the original. With the ease, speed, and global reach of Internet transmission, allowing digital exhaustion might threaten copyright owners' profits on a level not experienced before. ${ }^{86}$

\footnotetext{
${ }^{82}$ See, e.g., Kirtsaeng, 133 S. Ct. at 1390 n.27 (Ginsburg, J., dissenting).

$8_{3}$ Katz, supra note 5, at 145; see also, Ariel Katz, The First Sale Doctrine and the Economics of Post-Sale Restraints, 2014 BYU L. REV. 55, 77 (2014) [hereinafter First Sale Doctrine]; Guy A. Rub, Rebalancing Copyright Exhaustion, 64 EMORY L.J. 741, 775 (2015).

84 First Sale Doctrine, supra note 83, at 55; Katz, supra note 5, at 145-46, 164-66.

$85 \mathrm{Katz}$, supra note 5, at 165.

${ }^{86} \mathrm{Id}$. at 164 (and cited references therein).
} 
Moreover, digital exhaustion sometimes invokes the specter of facilitating unbridled piracy because nothing prevents people who sell their digital copies from simultaneously retaining them. ${ }^{87}$

These arguments rely on a series of plausible, but certainly not inevitable or incontrovertible, empirical predictions. They discount the myriad types of reasonable contractual restrictions that publishers could utilize, as well as the fact that publishers are better positioned than resellers to develop various strategies to compete with those resellers. For example, they can offer price-match guarantees, or they can discourage resellers by threatening to increase the supply of new copies, or they can offer bundles of work at a discount, and so on. Large and sophisticated resellers might offer their own inducements, but the copyright owner's control over the release of new copies provides publishers with a strategic advantage over the reseller whose supply of used copies will always be depended on and affected by the actions of the copyright owner. ${ }^{88}$

The specter of piracy-run-amok ignores the simple fact that as a matter of law a person who sells his copy but makes and retains another may still infringe copyright, and that as a practical reality, people who wish to evade the law do not need to masquerade as complying with first-sale rules when they can obtain illegal copies much more easily elsewhere. ${ }^{89}$ Moreover, even though it may be difficult to distinguish between a legitimate resale of a work in digital format and the sale of an illicit copy, law-abiding buyers of used works might prefer buying from reputable intermediaries ensuring the legitimacy of the transaction. ${ }^{\circ}$ Therefore, the ways in which recognizing digital exhaustion might increase the incidence of illicit copying are far from obvious. In fact, legitimizing second-hand markets for digital copies will allow individuals unable or unwilling to purchase new copies legitimately to buy used copies, which in turn reduces the demand for pirated copies. Such sales might not enrich copyright owners directly, but may benefit them indirectly, because consumers who know that they can resell the goods that they buy are

\footnotetext{
${ }^{87} \mathrm{Id}$.

${ }^{88} \mathrm{Id}$. at 165 .

${ }^{89} I d$.

90 See, e.g., Digitally Delivered Goods Policy, EBAY, http://pages.ebay.com/help/policies/downloadable.html [https://perma.cc/297U-K4PS].
} 
more willing to buy them in the first place. ${ }^{91}$ Moreover, the history of copyright teaches us that dire predictions about the devastating effects of digital and other technologies are frequently raised but have rarely materialized. ${ }^{92}$ It's true that the boy who cried wolf was eventually right, but it is also true that after repeated false alarms, the rational person becomes skeptical.

But more importantly, even if digital exhaustion presents new and different challenges for publishers, the arguments against it tend to focus on the short-term benefits that may accrue to copyright owners if the doctrine could be eliminated, or on the challenges facing them if maintained. But these arguments critically ignore exhaustion's longterm benefit to the public, and the harms to the public that will result from eliminating or narrowing it.

\section{Digital EXHAUSTION AND THE CASE OF LIBRARIES}

The social benefits of exhaustion and the harms that may result from eliminating or restricting it are not limited to libraries, although libraries provide an excellent case for demonstrating them. How we assess those benefits and harms depends on our understanding of the role and function of libraries, and how libraries interact with, and impact upon, the commercial market activities of publishers. In this Part, I discuss why libraries exist, the various market failures that they mitigate, and why many of those market failures will likely persist even with the advent of more advanced business models for the dissemination of works in digital formats.

\section{A. Why Do Libraries Even Exist?}

I opened this Article by highlighting the interesting fact that libraries engage in more transactions than publishers. I also noted that this ecosystem, where market-based remunerated transactions constitute only subset of a much larger number of non-market and non-remunerated transactions, has existed for generations-probably ever since publishers began publishing books and libraries began

\footnotetext{
${ }^{91}$ See e.g., Rub, supra note 83, at 782.

${ }_{92}$ Am. Broad. Companies v. Aereo, Inc., 134 S. Ct. 2498, 2517-18 (2014) (Scalia, J., dissenting).
} 
circulating them. How did this happen, and why has this equilibrium persisted?

One possible answer is that this is a historical error which the law has failed to rectify; instead of relying on publicly funded institutions (bureaucratic, slow to adapt, facing no market discipline, and no incentive to innovate), we could have let publishers (and other commercial intermediaries) take their place. Not only will commercial enterprise develop business models providing the same social benefits that we ascribe to libraries, but they could also do it in more efficient ways. Moreover, by monetizing the billions of transactions that are currently free, a market-based provision of library services will generate more profit for authors and publishers and therefore will increase the incentive to create new works. But as long as the law allows libraries to provide those free services and taxpayers continue to subsidize the libraries providing them, publishers cannot compete. Under this view, libraries should be privatized, or, at the very least, copyright law should be reformed to prevent libraries from providing their free services.

If this answer makes you jubilant, you can stop reading here. However, if you suspect that libraries provide services and play some roles that the market actors cannot or would not, then you may wish to continue reading.

\section{B. Libraries Mitigate a Web of Market Failures}

All but the most extreme market-fundamentalist economists could easily explain that libraries constitute one of several institutional responses to the market failures inherent in the copyright ecosystem. Therefore, libraries operate in a space that commerce does not and will not occupy, and the services that libraries provide supplement rather than compete with services that publishers and other commercial intermediaries could offer. If so, then the legal rules that facilitate the functioning of libraries (such as exhaustion) are efficient at least insofar as they permit beneficial activities that otherwise would not exist. Those rules might still be efficient even if libraries and commerce might compete at the margins (e.g., if some readers choose to borrow a book from the library even if otherwise they would buy it), so long as overall the social benefit from activities they facilitate outweighs whatever harms they cause. However, like any type of cost-benefit analysis, the conclusion that libraries increase efficiency by mitigating market failure is contingent on the types of market failures that exist in any specific context. As technology and 
business methods evolve, so may the existence or severity of different market failures. The cost of some market transactions might be prohibitively high under existing technologies, but new technologies or different organizational structures might reduce those costs and make it possible for new business models to emerge. If so, then recalibrating the respective roles of market and non-market institutions in the copyright system might be warranted.

Note how this framing might imply that libraries be permitted to provide only those services that publishers would not provide, and that by default, commercial (and copyright-dependent) models ought to be preferred over non-commercial models or models that are otherwise not based on copyright and exclusion. But this would be erroneous because copyright itself is an imperfect solution to a perceived market failure. Therefore, there is no a priori reason to privilege copyright-based models over other models for providing access to information. In fact, if services can be provided in ways that do not require incurring the social costs of copyright exclusion, a strong case can be made in their favor.

\section{Technology Contingent, Endemic, and Strategic Impediments to Access}

Consider the most typical of the activities of libraries: the lending of books. Some readers might prefer borrowing a book from a library to buying because its price exceeds their willingness or ability to pay, or because the book is out of print or otherwise not available for purchase in the relevant market (e.g., a book in a foreign language). In both cases, the fact that people borrow the book demonstrates that there is demand for the book that commercial market players (i.e., publishers or other commercial intermediaries) fail to supply. But why do publishers forego what seems like considerable missing business opportunities, and why do libraries occupy that space instead? Understanding what causes the mismatch between demand and supply by commercial entities is crucial for evaluating the respective roles of publishers, libraries, and the laws that regulate their activities.

Impediments to universal access to books can be classified into three general categories: technologically contingent impediments, endemic impediments, and strategic impediments. Technologically contingent impediments reflect the cost of printing, distributing, and storing the book (production costs). They also include the costs associated with running the business models under which those activities are pursued. Improvements in the costs of production may 
result in an increase in market-based provision of access. Endemic impediments to market provision reflect the public good nature of information and the inherent difficulties in determining the value of acquiring it. As a result, technological improvements are less likely to affect them. Lastly, strategic impediments result from the exercise of market power by publishers, which allows them to profit more by limiting production even if profitable production were otherwise feasible. I address those categories in more detail below.

\section{Technology Contingent Impediments}

Production costs affect how many books will be produced and sold; for any given demand curve, higher production costs would entail fewer books that will be produced and sold, and lower production costs will result in more books will be produced and sold. This suggests that when production costs are high, more people will depend on libraries for access, and when production costs decrease, the resulting lower prices will lead more people to buy their own copies instead of borrowing them from a library. For example, before the invention of the printing press, books were so expensive that not only were they beyond the reach of all but the wealthiest people, even if they were available in libraries, they were often chained to library desks and could not be borrowed. ${ }^{93}$ The printing press, by reducing the cost of printing, made books more affordable and their supply increased accordingly. 94 With further technological improvements, production costs decreased and supply increased.

However, the decline in the production costs (and prices) of books also means that libraries could purchase and lend even more books. The volume of such library transactions raises the question of why publishers (or other commercial intermediaries) don't seize the opportunity and offer their own for-profit library alternatives? The question already betrays an answer: the volume of library transactions may be high, but many of those transactions may not be profitable inasmuch as the cost of providing them exceeds the money that users might be able or willing to pay for them. Libraries, in this regard, resemble other business models based on the sharing of existing assets, such as the rental of homes or cars. Just as a car rental

\footnotetext{
93 See generally Joshua GANS, INFORMATION WANTS To Be SHARED (2012).

$94 \mathrm{Id}$.
} 
company allows people to drive a car even if they do not buy it, a library allows readers to borrow and read a book that they do not wish or cannot afford buying. The difference, however, between libraries and publishers or other commercial entities, is that, unlike libraries, these commercial entities will only provide sharing and other library services if those services could be profitable. Publicly funded libraries could offer those services even when they are not.

If this explanation provided the full answer to why libraries exist, it would be highly contingent on the technology of providing those services. New technologies and innovative business models may reduce production costs and create opportunities to profit from providing access to books. Technological advancements that reduce the costs of producing and selling books will tend to increase the sale of books and reduce the demand for and incidence of borrowing. Other technological changes may not only result in greater sharing, but might also induce entry of other players into the sharing space. Imagine, for example, an Uber-like service for book sharing, where instead of searching the catalog of the local library, people can search an online catalog of books that their neighbors are willing to lend them.

Likewise, changes in production costs can affect the incidence of borrowing out of print books. Assuming that the demand for older books is lower than the demand for newer books, and that the distribution and printing costs remain the same, publishers will rationally prefer using their limited resources for producing newer and more profitable books. Publishers will not print older books unless the expected revenue from their sale exceeds the cost of producing them. However, lower production costs might change the value proposition of older books: more of them might be printed and sold, and relatively fewer might be borrowed from libraries.

\section{Endemic Impediments}

Some impediments to market provision of access to books are more endemic and less contingent on the technology of production. Efficient market provision requires that actors have enough information on the costs and benefits of transacting, and that they fully internalize those costs and benefits. If buyers cannot determine the benefit of entering a transaction, or if some of the costs and benefits are borne by others (what economists call "externalities"), then market equilibrium will not reflect the social optimum. Therefore, a lack of information, together with externalities, may lead 
to market failure, and the creation of further endemic impediments to efficient market provision of access to books which technological advances cannot easily cure.

Books and other information goods present both of these problems. First, readers cannot fully ascertain the value of reading a book before they read it, and oftentimes even long after. In some cases, a book that seems promising turns out to be disappointing. In other cases, the value of what the reader learns today may only materialize fully when connected with knowledge obtained later, or when shared with other people. These unknowns present a pricing problem for readers and publishers. Readers struggle to determine whether the benefit from reading the book justified the cost of buying it, (and therefore forego at least some transactions for which the price seems too high ex ante). Publishers, facing readers with varying preferences, may find it difficult to determine an optimal market price (and therefore set a price that, for some readers at least, would be too high). Moreover, externalities compound these problems. A reader can only expect to internalize some of the social value of the knowledge she acquires, but not all of it. This is especially so when the reader acquires this information in order to share it with others (e.g., a teacher, researcher, a worker, or a manager). This is one aspect of knowledge being a public good. The benefits that accrue to others are positive externalities, which a reader will rationally ignore when deciding whether to pay for a book. In a similar vein, a profitmaximizing publisher will decide what to publish and at what price to sell it only on the basis of what maximizes its profit today or in the near future, and not on the basis of what maximizes social welfare in the long run. 95

Public libraries that provide free or heavily subsidized access to books reduce the social cost of these market failures and partially mitigate those endemic impediments to access. By allowing readers to access books for free, they improve the net benefit for the reader and thus increase readership towards the socially optimal level. Moreover, since their mandate reflects the long-term benefits of their communities and their funding depends on the public, public libraries

95 See, e.g., Brett Frischmann, Spillovers Theory and Its Conceptual Boundaries, 51 WM. \& MARY L. REV. 801, 812-13 (2009-2010). 
are more capable of providing access to books in a way that approximates society's long-term benefits. ${ }^{96}$

\section{Strategic Impediments}

The third type of impediments to access is strategic and reflects publishers' choices to limit access to books in order to maximize profit. I refer to these impediments as strategic because unlike the previous two types of impediments, which are exogenous to publishers' decisions, strategic impediments are fully dependent on publishers' choices. Strategic impediments result from and reflect publishers' market power, which allows them to increase profit by reducing output below the technologically feasible, and economically viable, level.

Copyright is one of the key factors affecting the price and availability of books. By limiting competition from other producers of the same book, the publisher can set the price at a supra-competitive level and earn a higher profit by reducing the quantity of copies available. As a result, people who are willing to pay a price that is higher than the cost of production but lower than the monopoly price are excluded from the market. This deadweight loss is not an unforeseen consequence of copyright, but an acknowledged cost of granting it. ${ }^{97}$ If copyright works as intended and drives the prices of books above the cost of their production, then the resulting unmet demand is independent of the technology of production and distribution. In other words, copyright, by design, leads to artificial scarcity, and therefore as long as there is copyright, institutions that mitigate the resulting deadweight will serve a purpose. $9^{8}$

In addition to limiting the supply and raising the price of printed books, copyright may also allow publishers to strategically limit or prevent the supply of older books. Since in many cases the marginal reader may regard an old book as a close substitute for a new book,

\footnotetext{
${ }_{96}^{6}$ The funding of libraries might still be lower than the optimal because the taxpayers that ultimately fund them might still prefer spending public money on purposes with more tangible and shorter-term benefits, and on those that benefit members of the immediate community over those that benefit society at large.
}

97 Ariel Katz, Making Sense of Nonsense: Intellectual Property, Antitrust, and Market Power, 49 ARIZ. L. REV. 837, 841 (2007).

98 Wendy J. Gordon, Intellectual Property As Price Discrimination: Implications For Contract, CHI.-KENT L. REV. 1367, 1388 (1998). 
increasing the supply of older books might have the same depressing effect on the price of new books as printing a larger quantity of the new book. Therefore, many older books are out of print and unavailable not only because the cost of supplying them relative to the demand for them makes their production non economical, but because copyright allows publishers who hold large portfolios of copyright to strategically choose which books to continue producing, and which books to suppress. 99

Therefore, when impediments to market based provision of access to books are strategic, libraries may reduce the resulting deadweight loss by facilitating access to those books. Libraries can do this because copyright law permits libraries to provide certain forms of access without the copyright owner's permission.

\section{Price Discrimination and Impediments Thereto}

The copyright explanation is incomplete, however, because while copyright allows publishers to price books at a supra-competitive level, copyright law also allows copyright owners to implement pricediscrimination schemes that could generate even higher profits. ${ }^{100}$ If the copyright owner could charge the higher monopoly price to those who are willing to pay it, and set a lower price for those who are not, then not only will the copyright owner be able to earn even higher profits (meaning greater incentive to invest in the first place), it would be achieved with no, or at least smaller, deadweight loss. In cases where a monopolist could charge every user a price that corresponds to that user's ability or willingness to pay, the monopolist will produce the same quantity that will be available under perfect competition while earning much higher profits. ${ }^{101}$

In order to price-discriminate, the seller must have: (i) some market power (i.e., power to set the prices above the marginal cost of production, which copyright, by preventing other producers from producing the same book, usually confers); (ii) an ability to have

\footnotetext{
99 See generally Paul J. Heald, How Copyright Keeps Works Disappeared, 11 J. EMPIRICAL LEGAL STUD. 829.

100 See, e.g., Gordon, supra note 98.

101 James Boyle, Cruel, Mean, Or Lavish - Economic Analysis, Price Discrimination and Digital Intellectual Property, 53 VAND. L. REV. 2007, 2025-26 (2000); see also Rub, supra note 83 , at 766 .
} 
sufficient information about users' preferences and willingness and ability to pay combined with the ability to sort them out accordingly; and (iii) an ability to prevent arbitrage: that is, to prevent a user who purchased the good at a lower price from reselling it to another user who would otherwise be willing to pay a higher price to the copyright owner.

Digital technologies promise greater potential for profitable pricediscrimination insofar as they can improve the ability to gather information on users and offer a more finely-tuned array of products, services, and prices to match heterogeneous demand. From this perspective, exhaustion could be seen as presenting a serious problem: it reduces the copyright owner's power to prevent arbitrage because it makes it lawful for a person who purchased a book at a lower price to resell it to another reader who would otherwise be willing to pay a higher price. Further, it facilitates secondary markets of used books that can be sold in competition with the higher-price offerings of the publisher. In addition, by permitting resale transactions that do not require the copyright owner's permission, exhaustion interferes with the copyright owner's effort to collect information on its users. Those who believe that ubiquitous price discrimination creates a strong incentive to create and disseminate new works are inclined to endorse the view that (a) exhaustion should not apply to the transfer of digital files, and (b) even if it did apply, copyright owners should be able to circumvent it using technological means, license restrictions, or contracts. In the same vein, they might tend to see the library (and its reliance on exhaustion) as an institution that might have mitigated the market failures of yore, but whose continued existence is obsolete at best, and at worst represents a threat to the growth of new business models.

Earlier critics of these views assumed that this model of ubiquitous price discrimination is indeed possible, though some of them have questioned whether it is also desirable. ${ }^{102}$ They questioned, for example, the overly optimistic, and sometimes simplistic, assumptions that proponents of the ubiquitous price-discrimination vision make, ${ }^{103}$ and highlighted that the move from one regime to another is not necessarily value neutral ${ }^{104}$ and may influence the type of works that

${ }^{102}$ See, e.g., Julie Cohen, Copyright and the Perfect Curve, 53 VAND. L. REV. 1799 (2000); Gordon, supra note 98.

${ }_{103}$ Cohen, supra note 102, at 1809-10.

104 Boyle, supra note 101, at 2027. 
are created and used. ${ }^{105}$ Others have noted that price discrimination does not necessarily result in greater output, and might result in less access, rather than more. ${ }^{106}$

I would like to add to this debate by focusing on the type of information that would be necessary to implement ubiquitous price discrimination, whether gathering it is possible, and why publishers might strategically choose not to implement the vision of ubiquitous access-maximizing price discrimination, even if they could. This discussion will reveal that there are some endemic impediments to efficient price discrimination, as well as some strategic reasons why publishers might refrain from implementing it, even if they could. This discussion will also provide important insights about why some of the roles of libraries are economically indispensable, while other roles are politically crucial.

In order to implement a system of efficient and ubiquitous price discrimination that achieves the optimistic vision for which its proponents advocate, publishers should be able to amass large amounts of information on users, which users might have very little incentive to supply, good reasons to keep private, or at least disclose strategically (i.e., to provide information they believe the publisher will interpret as signaling low willingness or ability to pay). However, even if users were willing to candidly provide full information, the information would still be incomplete, because users themselves may not know what they will learn from reading a book they have not read, or what utility they might derive from it. Moreover, even if the publisher were willing to take the information that the user provides at face value (which they should not) before setting a price, a rational publisher would still need to interpret the information. But the more idiosyncratic the individual user's preferences and intended use are, the more difficult and prone to error is the task of setting a "correct" individual price.

Furthermore, many limitations on copyright permit users to engage in activities that benefit not only the users themselves, but also third parties and society at large. These users, however, can expect to internalize only part of the social benefits arising from their activities and will not take into account the positive spillovers conferred on

\footnotetext{
105 Glynn S. Lunney, Jr., Copyright's Price Discrimination Panacea, 21 HARV. J.L. \& TeCH. 387, 448 (2007-2008).

${ }^{106}$ See e.g., Guy A. Rub, Contracting around Copyright: The Uneasy Case for Unbundling of Rights in Creative Works, U. CHI. L. REV. 257, 268 (2011).
} 
others. For example, a reader may buy a book and then decide to write a critique of it; or the book may inspire her to write additional works. If that reader has to pay for the right to criticize the book or for the right to be inspired by it, her willingness to pay will reflect only the private value that she might expect to derive from these activities, but not the value that her activities will generate to others. ${ }^{107}$ Copyright owners ignore those positive spillovers as well and would be especially reluctant to permit uses that might harm their own interests. Or, copyright owners might strategically exploit situations of hold-up to extract the highest licensing fees possible. Consequently, even if publishers could implement mechanisms that provide access to all readers, the terms of those transactions will not result in a socially optimal equilibrium. ${ }^{108}$

Strategic reasons might also deter publishers from implementing less-than-perfect price discrimination. As noted above, publishers may choose to keep older books out of circulation for strategic reasons, rather than cost-related reasons. In addition, while digital technologies provide tools that could be used for more effective price discrimination, they also create unique strategic challenges. For example, large-scale printing technologies typically involve considerable set up costs, which compel the publisher to determine in advance the number of copies in each print run. Printing additional copies would entail incurring the set up costs again (as well as the opportunity cost of printing this book rather than another book), and the publisher will only incur them if it expects that the demand for the additional run will generate enough profit to cover those costs. Even though the information embodied in the book is non-rivalrous, the book itself is rivalrous and the limited quantity of printed copies forces the buyer to reveal how much she values the book (or at least she values getting a copy of the book more than other potential buyers against whom she is bidding).

This is not the case with fully digital books, such as e-books, where the marginal cost of producing another copy or authorizing another use is close to zero, and where communicating with any potential user is easy. These features entail that once the publisher produces a digital copy of a work, it effectively has the capacity to supply the entire

107 Frischmann, supra note 95.

${ }^{108}$ First Sale Doctrine, supra note 83, at 107-08. 
demand for it. ${ }^{109}$ As a result, selling or licensing a digital book to one person does not diminish the opportunity to sell it to another. Since users are no longer bidding over a resource with finite quantity, there are fewer reasons for them to reveal how much they are willing to pay, and greater reasons to stall and pretend to be a marginal consumer further down the demand curve, who values the work just slightly above the marginal cost of its production. Having built the capacity to supply the entire demand, the publisher cannot credibly threaten not to sell or to sell to someone else and should, in theory, be willing to accept any price above zero. The key difference between the printed book and the e-book in this regard is that the traditional technology of printing results in scarcity (at least temporarily), which allows publishers to reliably commit to selling the book at prices that exceed marginal costs. In contrast, there is no equivalent technological impediment to producing another e-book instantly. ${ }^{110}$ Paradoxically, the very conditions that make the online provision of digital goods so amenable to ubiquitous price discrimination can also make it unattractive for publishers to so discriminate. ${ }^{111}$

If we assume that publishers can implement perfect price discrimination (not near perfect, but perfectly perfect) then we assume away these challenges. So let's imagine, that sophisticated big data tools will allow publishers to create a precise profile of every user that will not only determine that user's precise preferences, but also predict their social utility with perfect accuracy, without being tricked by any attempt to pretend to have a lower willingness to pay. And if we take the promise of perfect and ubiquitous price discrimination seriously, we should also contemplate harnessing the power of the state to ensure that the collected data is both complete and accurate, and that attempts to undermine the system by not providing publishers full and accurate disclosure of all necessary data or through arbitrage will not be tolerated. In other words, accomplishing the optimistic vision of ubiquitous price discrimination might involve

\footnotetext{
109 This may also be true for digital print-on-demand.
}

110 This type of pricing challenge is reminiscent of the pricing challenges that monopolists selling durable goods face. See generally R.H. Coase, Durability and Monopoly, 15 J.L. \& ECON. 143 (1972); Barak Orbach, The Durapolist Puzzle: Monopoly Power in DurableGoods Markets, 21 YALE J. ON REG. 67 (2004).

${ }^{111}$ This might explain, at least in part, publishers' reluctance to embrace e-books and why the resorted to various techniques, some of them illegal, in their attempt to prevent the sale of cheap e-books. See United States v. Apple Inc., 952 F. Supp. $2 d 638$ (S.D.N.Y. 2013). 
intrusive surveillance mechanisms that can seem decidedly Orewllian. ${ }^{112}$ One may notice that a capitalist's ideal of ubiquitous price discrimination resembles the utopian socialist "from each according to his ability, to each according to his needs", not only in their outcome, but also in the means that might be necessary to accomplish them. ${ }^{113}$

The dependency of ubiquitous price discrimination schemes on intrusive surveillance demonstrates that historically libraries have offered not only access to books, but have also endeavored to provide access under conditions that guarantee readers' privacy and freedom from surveillance. To the extent that readers value the ability of reading without being watched, libraries offer them a service for which the market cannot, or may not, easily substitute. Moreover, because readers cannot internalize the entire social benefits that stem from an environment that enables this kind of free inquiry, they may rationally waive their privacy in return for more immediate and tangible commercial offerings. Therefore, to the extent that society has an interest in preserving an environment that promotes free, anonymous, and private inquiry, libraries and the legal rules that enable their operation are worth keeping, even if the market could otherwise provide seemingly comparable services. ${ }^{114}$

\section{E. Alternatives to Direct Price Discrimination}

If amassing the data required for implementing perfect or nearperfect price discrimination now seems impossible, or if we consider the necessary conditions for it undesirable, then publishers could still resort to other forms of price discrimination. They could offer a menu of options for accessing works, catering to readers with different

${ }_{112}$ Christina M. Mulligan, Personal Property Servitudes on the Internet of Things, 50 GA. L. REV. 1121 (2016). See also Boyle, supra note 101, at 2034 ("Perfect price discrimination requires more information about customers than can be revealed by mere self-selection and more information-gathering (to prevent illicit arbitrage, lending, or gifts). Do we really want to commit ourselves to a regime that will offer companies major assistance in the form of state power, assistance that will yield them big bucks, but only if they monitor their customers superlatively well? This seems like a rather perverse set of incentives.").

${ }^{113}$ But with a major difference, as Oren Bracha reminded me: proponents of ubiquitous price discrimination tend to conflate the concepts of "needs," "willingness to pay," and "ability to pay."

${ }^{114}$ See generally Julie E. Cohen, A Right to Read Anonymously: A Closer Look at "Copyright Management” in Cyberspace, 28 CoNN. L. REV. 981 (1996). 
preferences and letting readers reveal their preferences by choosing the version that suits them best (economists often refer to this as second degree price discrimination). Alternatively, publishers can offer a single version of the work, but charge prices on the basis of easily observable characteristics that serve as a proxy for willingness or ability to pay (economists often refer to this as third degree price discrimination).

Publishers have used these methods for years. For example, the difference in price between hard cover and paperback typically exceeds the difference in the cost of production, and their sequential release serves as a method for second-degree price discrimination: eager and more affluent readers may rush to buy the hard cover edition, while less eager or less affluent readers might wait for the paperback. The higher durability of hard cover books may also make them more appealing to libraries because it reduces the wear and tear that may result from the circulation of the copy among different readers, and libraries might be willing to pay a premium for this additional functionality. Discounts offered to students and seniors (which presumably earn less and have lower ability to pay) are a common form of third degree price discrimination, because those characteristics can be easily observed or at least verified.

While perfect price discrimination could, in theory, maximize both access and profit, other types of price discrimination could increase profit (otherwise publishers wouldn't implement them voluntarily) without resulting in full or even greater access, compared to the level of access under uniform pricing, let alone when the role of non-market access (e.g., through libraries) is counted. Therefore, even considering only the narrow economic question of how many people gain access, imperfect price discrimination is not a priori preferable to other mechanisms.

There are three additional techniques that have enabled publishers to indirectly accomplish outcomes equivalent to those under direct price discrimination: the first is through the bundling of content, the second is through permitting or tolerating sharing of content among users, and the third is through a combination of both. As the next section shows, publishers employ these techniques routinely, and in many cases, libraries form part of the ecosystem that enables them. 


\section{F. Indirect Price Discrimination: Bundling, Sharing, and Libraries}

The bundling of content in a single object (e.g., an issue of a newspaper or a magazine) or in a license that pertains to different works (e.g., subscription to a bundle of cable channels, or a database of journal articles, or a streaming services such as Netflix) allows the content provider to achieve the effect of price discrimination without needing to know how different consumers value different works. Bundling achieves this result because, even though readers' tastes, preferences, and willingness to pay with respect to individual works will vary significantly, their willingness to pay for a bundle tends to average out. ${ }^{115}$

For example, imagine two brothers, Jacob and Esau. Both like to be informed about what is going on in the world, but they have somewhat different interests and preferences: Jacob spends more time on op-eds than on news, while Esau does the opposite. In addition, Jacob likes to read articles on food and style, while Esau prefers stories about hunting and adventures (though he will not miss a recipe for good lentil stew). If the publisher of Canaan Times could determine exactly how much each of them is willing to pay for each article, it could maximize profit by setting such individual prices and selling individual articles accordingly- but obtaining such information is nearly impossible. ${ }^{116}$ However, the price that each of them is willing to pay for a bundle that includes various articles tends to average out, regardless of the variance in their respective preferences for individual articles. Therefore, bundling the different article in an issue of the newspaper makes it easier for the publisher to predict how consumers will evaluate a collection of works, without needing to know how they value any individual work. ${ }^{117}$

The publisher can combine this strategy with other indirect forms of price discrimination. For example, if Esau, the farmer and hunter who never went to university, is less affluent than his erudite brother,

\footnotetext{
${ }^{115}$ See Yannis Bakos \& Erik Brynjolfsson, Bundling Information Goods: Pricing, Profits, and Efficiency, 45 MGMT. SCI. 1613 (1999). See also GANS, supra note 93, at 27.

${ }^{116}$ News articles, and most other copyrighted works are experience goods, meaning that buyers cannot ascertain their quality before buying them. This makes per-work per-user pricing even more challenging.

${ }^{117}$ See, e.g., Ariel Katz, Commentary: Is Collective Administration of Copyrights Justified by the Economic Literature?, in COMPETITION POLICY AND INTELLECTUAL PROPERTY (Marcel Boyer et al. eds., 2009).
} 
then offering the bundle at a discount to members of the Hunters and Farmers Association could increase the publisher's profit.

Now, suppose that Esau, after settling in Edom, prefers The Edomite to the Canaan Times as his main source of information, but is still interested in reading the Canaan Times occasionally. At the same time, the educated Jacob, who generally prefers the Canaan Times, enjoys reading stories from The Edomite now and again. Each of them would be happy to subscribe to both newspapers, but the full price of a subscription to The Edomite exceeds Jacob's marginal utility from reading that newspaper-and vice versa with respect to Esau paying for a subscription to Canaan Times. If the publisher of The Edomite offered Jacob a substantial discount on a subscription, Jacob would buy it, and Esau would do the same with respect to the Canaan Times. However, the cost of determining what the prices should be and of maintaining a system for such differential pricing exceeds what each of the publishers could gain from implementing it.

Moreover, their inability to afford subscribing to another newspaper does not really prevent the brothers from reading articles from the other newspaper because they often share them: once a month Jacob sends the used issues of the Cannan Times to Esau, and Esau does the same with his used issues of The Edomite. And occasionally, they might even scan selected articles of special interest and email them to each other so that they can be read much sooner; or, they simply email links to articles from the online edition of the newspapers (their respective lawyers advised them that the first-sale doctrine allows them to mail the used issues to each other, that reproducing and emailing the occasional article will likely qualify as fair use under the circumstances, and that emailing a hyperlink does not normally give rise to any copyright concerns).

Although this arrangement may not be as convenient as being fully subscribed to a second newspaper, the brothers find this solution satisfactory. Moreover, each of them also realized that this sharing allows them to maintain their otherwise complicated relationships, and that by being able to share their newspapers with each other their respective subscriptions became more valuable to them: so much so, that even though both of them were hit by the Great Recession and had to reduce their expenses, the brothers-unlike some readers who cancelled their subscriptions (and had to be induced with significant discounts to re-subscribe)-retained their respective subscriptions.

When the publisher of the Canaan Times decided to charge for full access to its online edition, limit the number of articles that nonsubscribers could access, and offer an online-only subscription that 
costs less than full or print-only subscription, Esau considered buying the online-only subscription, but the price was still too high for him. Jacob, however, was happy to upgrade his subscription and get the full print-plus-online version, and share his login credentials with his brother.

Not only did the various ways in which the brothers legally shared newspaper articles not hurt the publishers, they probably benefited them financially because the unpaid sharing increased each of the brothers' willingness to pay for the content they paid for, and allowed the publishers indirectly to achieve an outcome similar to those under direct price discrimination without incurring the costs that setting up direct price discrimination schemes demand. Moreover, these beneficial outcomes are possible because copyright law permits them.

Publishers routinely sell or license content in ways that are consistent with the economics of bundling and sharing as a means of indirect price discrimination. For example, the traditional method of distributing scientific articles has been bundling them in issues of journals, which, in turn, are distributed mainly to subscribers. This method involves two levels of bundling: allowing readers to access all the articles bundled in a single issue, and allowing subscribers to access all the issues within the subscription period. Digital technologies enabled even greater levels of bundling, where users gain access to even the larger bundles available through large databases of journal articles.

Common practices are also consistent with the economics of indirect price discrimination via sharing. The market for academic monographs and specialized reference books tend to be small (relative to, say, novels or magazines). It consists of readers with varying and idiosyncratic types of uses who might be interested in reading the book or sections of it in highly unpredictable ways over long periods of time. Moreover, the utility that users derive is often uncertain, and not easily internalized by the reader (e.g., in the form of pleasure or by charging a client). While developing an effective direct price discrimination scheme for this type of literature seems dauntingly difficult, if not impossible, publishers can still deploy at least two types of indirect price discrimination. Many of these books are sold primarily to libraries who allow readers to share them, either through lending or through photocopying of excerpts. A library is willing to pay a higher price than most of its patrons would be willing to pay because it provides patrons a valuable service, and its continued funding depends on satisfying the needs of its patrons. In essence, the library internalizes the preferences of its patrons and allows the 
publisher to set a higher price for the book without worrying about trying to determine the preferences of individual readers. Effectively, these books are meant to be shared and publishers price them accordingly. In addition to libraries, select individuals who need permanent access to those books or otherwise prefer the benefits that are incidental to full ownership of a copy of a book might also be willing to pay the typically high price of those books.

These observations go some way towards explaining why the present ecosystem, where market-based remunerated transactions constitute only a subset of a much larger number of non-market and non-remunerated transactions, has existed for generations, and why there is no a priori reason why it could not continue to exist with respect to digital content.

These observations do not imply that the legal rules that facilitate sharing (including exhaustion and fair use) necessarily benefit copyright owners in every instance. Sharing benefits copyright owners unambiguously only when no unpaid use substitutes for paid uses, or when the additional profit that result from greater willingness to pay for sharable content outweighs the losses from substitution. Moreover, the legality of sharing makes it more difficult for the publishers to implement direct price discrimination schemes that, if practicable, would be even more profitable. When users' gain merely offsets this forgone profit for publishers it has no effect on total welfare, but the prospect of gaining this additional profit could, at the margin, influence a publisher's decision whether to invest in a particular project or not. Arguably, if lower expected profit discourages publishers from investing in otherwise profitable projects, readers are harmed as well. If so, then it might be tempting to conclude that copyright owners should be granted the power to control all sharing; if they expect that the benefits from sharing will be greater than the losses of sharing they will rationally allow it, but if the sharing interferes with their ability to implement profitable price discrimination schemes they will disallow it. For libraries, this implies that publishers should be able to fully control what libraries do and to what extent.

As tempting as this view might be, however, it is only attractive if one assumes that the interests of publishers and the interests of society are constantly aligned. As noted in the earlier discussion, they are not. Even if we assume that technology could eliminate all technological impediments to efficient market based access to books, it cannot eliminate all of the impediments that are endemic to the nature of information goods. Moreover, granting copyright owners 
control over all forms and types of sharing provides no guarantee that they will exercise it in benign welfare enhancing ways, rather than in ways that strategically maximize profit while reducing overall welfare. And once we add the liberal values of democracy and freedom into the welfare equation, the inescapable conclusion is that perfect price discrimination (even if technically feasible) may not be welfare maximizing, because its accomplishment requires a legal infrastructure that is inimical to those very values.

This analysis suggests that if the copyright ecosystem has a public purpose, then some of the functions that libraries perform are not only fundamental but also indispensable for attaining this purpose. Therefore, the legal rules (such as exhaustion and other limitations on copyright) that allow libraries to perform these functions are as integral to the copyright system as copyright itself. ${ }^{118}$

\section{CONCLUSIONS}

In this Article I presented and challenged the view that the firstsale doctrine, or exhaustion, applies only to the transfer of tangible copies of works from one person to another- but not to the transfer of digital files. Under this view, the first-sale doctrine merely exists as a statutory exception, and one that limits only the copyright owner's distribution right, but not other rights. It protects defendants who can show that their acts fall within the bounds of the statutory exception, but any incongruence with the statutory exception would be fatal to their defense. This view, in turn, depends on certain assumptions about the meaning of the several exclusive rights, the meaning of the first-sale doctrine, and what the interaction among them entails. I demonstrated that none of these assumptions is self-evident. The law on digital exhaustion is anything but settled, and is capable of being interpreted differently. As a "first sale" doctrine it may limit only the distribution right, but its statutory presence might merely affirm a broader principle of exhaustion-one of several principles in copyright law that limit the copyright owner's powers. The principle of exhaustion can apply, and at times has been applied, beyond the distribution right.

I also showed that copyright owners' ability to escape exhaustion by characterizing transactions as "licenses" rather than "sales", or by using contracts to exercise downstream control is hardly a foregone

${ }^{118}$ Compare CCH v. LSUC, [2004] S.C.C. 13 (Can.). 
conclusion. Established precedent and sound legal principle indicate that while the law recognizes some scope for contracting around exhaustion, courts will not necessarily uphold any private reordering of the respective legal entitlements of copyright owners and users. How those principles will apply to digital exhaustion is, at most, unsettled. I argued that the doctrine of restraint of trade provides a well-known (albeit somewhat neglected) legal framework for distinguishing between those limitations on exhaustion that are reasonable and justified and those that are not.

While these observations and conclusions apply to exhaustion generally, they apply most demonstrably in the case of libraries. Libraries occupy a privileged space in the copyright system. Historically, libraries predate copyright, and the institutional role of libraries and institutions of higher learning in the "promotion of science" and the "encouragement of learning" was acknowledged before legislators decided to grant authors exclusive rights in their writings. The historical precedence of libraries and the legal recognition of their public function cannot determine every contemporary copyright question, but this historical fact is not devoid of legal consequence. History is part of the legislative history of statutes, and it constitutes part of the context that informs the interpretation of current statutes. Specifically, if one proffered interpretation of the Copyright Act threatens to seriously curtail the function of libraries, courts should require a clear indication that this was the intended goal of the legislation before adopting it. Taken together, the first parts of this Article demonstrate that the conclusion that the current legislation does not allow digital exhaustion is at least questionable, if not false.

Looking forward, whether digital exhaustion should be preserved or permitted depends, in the case of libraries, on understanding their function, and how they might be impacted by digital technologies. In analyzing the role of libraries in facilitating non-market access to books, I identified three types of impediments to efficient marketbased access: technology contingent impediments, endemic impediments, and strategic impediments. I noted that technological changes might only lead publishers to develop market-based models of access that are technology contingent, but market-based models aren't likely to displace the role of libraries when libraries address endemic or strategic impediments. More specifically, I explained why digital technologies and the abolition of exhaustion would not result in perfect price discrimination, and that exhaustion has not and will not prevent publishers from continuing to implement indirect 
methods of price discrimination. Since giving publishers greater powers to implement imperfect modes of price discrimination will not necessarily lead to superior outcomes relative to the current ecosystem, there is no a priori reason to assume that eliminating digital exhaustion will increase social welfare. In fact, because profitmaximizing publishers will prefer models that increase their private returns while ignoring the long-term effects on society, the prudent assumption is that eliminating digital exhaustion will not increase social welfare. Libraries, institutionally designed to consider the collective long-term benefits of access to knowledge would therefore continue to play an indispensable role in providing access to works in digital formats, and policy-makers should insist that strong evidence be presented before they are willing to discard this assumption.

As long as the copyright ecosystem has a public purpose, then some of the functions that libraries perform are not only fundamental but also indispensable for attaining this purpose. Therefore, the legal rules (such as exhaustion and other limitations on copyright) that allow libraries to perform these functions remain, and will continue to be, as integral to the copyright system as the copyright itself. 
